\title{
Why Spatial Planning Often Fails to Control the Spreading Locations of Large Scale Commercial Facilities?
}

\author{
Tatsuo Akashi \\ Department of Urban Life Studies, Tokyo City University, Tokyo 158-8586, Japan
}

\begin{abstract}
The purpose of this paper is to clarify the mechanism of planning failure on land use control in case of sprawl developments of large scale commercial facilities, which is often seen in many countries. The author demonstrates actual three cases in Japan: a huge commercial development established in the middle of rice field between the two local cities, two huge commercial accumulations established at the opposite fringes of urban area, and many large commercial developments established one by one within the small municipalities surrounding a central city. And by examining the statistical sales amount, the author describes that these huge suburban commercial developments apparently deprived the sales of the downtown. Through analyzing these cases, the author empirically stated that for the motorized local cites, the optimum location of commercial accumulation is no longer the central area of the city but about 15 min away from the center with the smooth accessible arterial road. At last, the author mentions that the "planning failure" could be occurred if the territory of planning authority and the scale of the development are inconsistent, such as the authority of small municipal government and the large scale commercial facility which impacts beyond the municipal boundary.
\end{abstract}

Key words: Large scale retail store, urban sprawl, social inclusion, catchment area.

\section{Introduction}

Evolution of retail industry in recent decades largely influenced the form of urban land use and spatial structures in many cities in the world, especially regarding location of commercial accumulation districts which are places where large number of residents visit. The traditional land use pattern was a city having downtown as a prominent commercial centre with large department stores. It has already became an old tale, even in regional core cities. Instead of that, huge shopping mall developments in suburban areas, and even outside of urban areas, are quite common.

In addition to location, size of retail establishments has increased tremendously. A single new retail development in the suburbs with almost the same scale of floor area as retails in the whole traditional

Corresponding author: Tatsuo Akashi, Ph.D., professor, research field: spatial planning. E-mail: tatsuoak@tcu.ac.jp. downtown is not unusual today. Typical size of a suburban shopping mall (more than 10,000 $\mathrm{m}^{2}$ ) exceeds the normal size of supermarket (some thousands square meters), and far exceeds the size of a roadside shop (some hundreds square meters). Typical suburban-type commercial accumulation in these days consists of a huge indoor shopping mall and some surrounding large stores. They have huge amount of parking space for automobile customers with thousands of parking lots in the districts.

Understandably, these retail developments with more than ten thousand square meters forth changed their location from the traditional downtown to suburbs, or even sometimes to outside of a city. As a matter of course, the influence is not small. The most crucial problem caused by retail sprawl is alienation of people who do not use automobile. Even though automobile users are majority while people who do not use automobile cannot be neglected. According to public opinion survey by the national government of 
Japan in 2005 [1], for instance, people who do not use personal vehicle is $28 \%$, and the reasons are that "because I do not drive by myself" is $45 \%$ and "because I do not have car" is $28 \%$, whereas, people who always use personal vehicle is $57 \%$.

The purpose of this paper is to clarify the necessity of a regional perspective of land use control in order to prevent the phenomenon of sprawl developments of large scale commercial facilities in matured motorization era. In order to clarify the mechanism of huge retail accumulations established in outskirt of a city, this paper introduces three simple but true cases observed in Japan, using the two statistic data by METI (Ministry of Economy, Trade and Industry of Japan) such as "Census of Commerce" and "Annual Report on Registration of Large Scale Retail Stores". Further, given the cases, the author points out that a municipal government with small territory is not an appropriate body on land use of facilities with large catchment area such as large retail establishments because neighbourhood municipalities are in competitive position with each other.

Seeing the previous researches, spreading location of large scale commercial facilities seems a relatively common problem among developed countries, but approaches to control them are rather diverse [2]. Among them, UK government approach has been the most strategic in terms of planning methodology [3] since 1996, especially the part of "sequential approach" that is a unique criteria for judging location of large scale retail establishments. The planning policy guidance was refined to the planning policy statement [4] that refers to social inclusion policy as one of the expanded reasons to control location of retail stores. Analyses of diverse impact by establishing large scale commercial facilities based on actual case have been implemented (Refs. [5, 6] for example), and there is an indication of difference between local government and the national inspectorate of UK in implementation of PPG6 [7]. In these contexts, this study approaches to clarify the fact that failure of planning can happen when impact area of the development is larger than the territory of municipal government, that is, if the spatial scale of development impact and regulatory authority would not be consistent through case studies of large scale commercial facilities located in outer area of the city.

In view of location theory, there is a classical but famous theory called Hotelling model known as "ice cream vender on the beach" [8]. The question is that when customers are in line of under beach umbrellas at equal intervals, where is the optimum location of two ice cream venders? The answer should be in the middle of the line and the two venders should be arranged back to back. This is considered as a theoretical reason why the traditional commercial accumulation is in the central area of the city. However, customers on the beach are all pedestrians. Then, when it comes to change from pedestrians to automobile users, does the optimum location for retail accumulation change? This study provides the actual examples of the answer.

\section{Case 1: A New Retail Accumulation between Two Cities}

\subsection{Outline of the Case Cities}

The first case is a new large retail accumulation developed in the midst of rice field area between two cities. Around the district where the new large retail stores were developed, there was nothing but rice field and an arterial road that connects two cities. However, soon after the large stores opened, sales power of two downtowns in the two cities rapidly shrank and decreased.

The names of the two cities are Tsuruoka City and Sakata City. Both cities are in Yamagata prefecture, located in the northern part of the main island of Japan. They have similar size of population. Tsuruoka City has approximately 130,000 people, while Sakata City has 110,000 . The locations of the two cities are both 
in Shonai plane with approximately 53,000 ha of flat fields combined with the sea and mountains. The two cities are functioning independently. Distance between the downtowns of the two cities is approximately $20 \mathrm{~km}$.

\subsection{What Happened?}

Fig. 1 and Table 1 show the comparison between before and after the new large retail stores were between the two cities. Fig. 1a describes the retail situation in the region in 1997 which is "before". The largest retail accumulations in the region were seen in two downtowns of the two cities: downtown Tsuruoka with $38,648 \mathrm{~m}^{2}$ of total retail floor and downtown Sakata with $39,497 \mathrm{~m}^{2}$ (both in 1997). Seeing the aspect of total annual retail sales in 1997, downtown Tsuruoka's sales were 24,814 million yen. whereas downtown Sakata's were 24,781 million yen. In the "before" period, the two downtowns were definitely in the position of the retail centres of the region.

Fig. 1b shows the situation in 2007 after the large retail accumulation was developed. The new commercial development was located in the territory of Mikawa Town just in the middle of the two downtowns, approximately $10 \mathrm{~km}$ away from the both downtowns. Mikawa Town is a different municipality from both the two cities.

The total retail floor area of the newly developed retail district reached to $51,299 \mathrm{~m}^{2}$ and the annual retail sales reached 15,340 million yen (both in 2007). As comparing it with the two downtowns by data of after it was developed, both of the two downtowns have shrunk and decreased, 27,712 $\mathrm{m}^{2}$ of floor and 13,204 million yen of sales in downtown Tsuruoka, and $25,967 \mathrm{~m}^{2}$ and 11,979 million yen in downtown Sakata (both in 2007). According to these data, the newly developed retail district definitely affected the old two downtowns, and moreover, it got the position of the largest retail centre in the region in terms of both floor area accumulation and amount of sales. On the contrary, the positions of the two downtowns as regional retail centres largely fell and declined.

\section{Before (1997)}

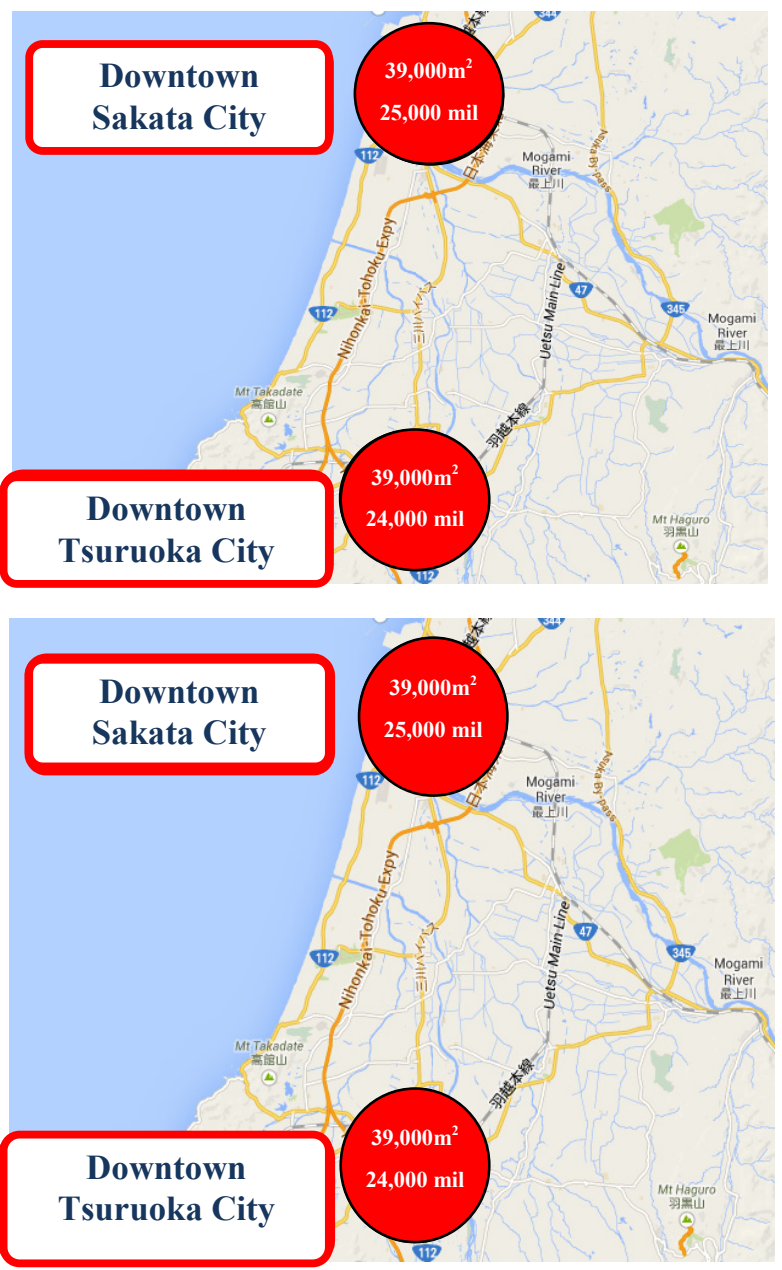

(a) Retail stores in 1997

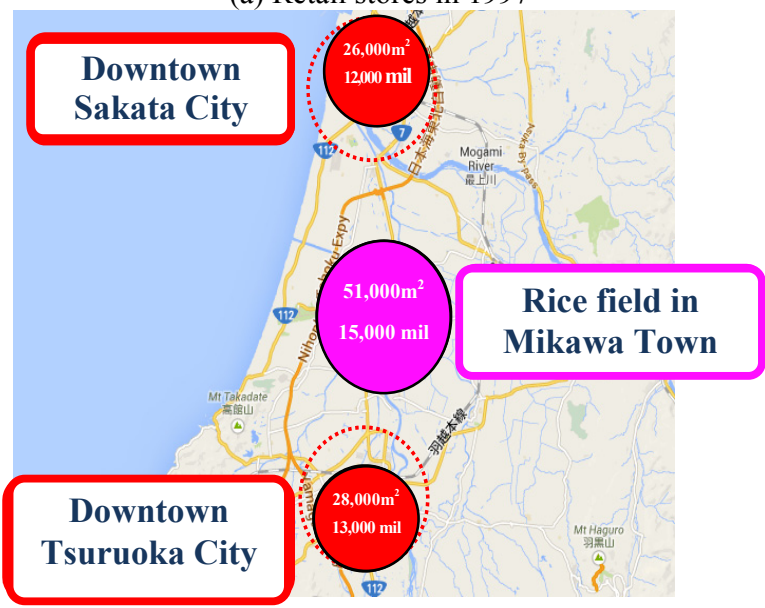

(b) Retail stores in 2007

Fig. 1 Change of retail accumulation $(1997,2007)$. 
Table 1 Change of floor and sales of retail accumulation (1997 to 2007).

\begin{tabular}{lllll}
\hline \multirow{2}{*}{ Retail accumulation } & \multicolumn{2}{c}{ Year } \\
\cline { 3 - 5 } & Downtown Tsuruoka City & 1997 & 2002 & 2007 \\
\hline \multirow{3}{*}{ Floor } & Downtown Sakata City & $38,648 \mathrm{~m}^{2}$ & $40,469 \mathrm{~m}^{2}$ & $27,712 \mathrm{~m}^{2}$ \\
& Large stores in Mikawa Town & $39,497 \mathrm{~m}^{2}$ & $28,502 \mathrm{~m}^{2}$ & $25,967 \mathrm{~m}^{2}$ \\
& Mikawa/Both downtown & - & $23,817 \mathrm{~m}^{2}$ & $51,299 \mathrm{~m}^{2}$ \\
\hline \multirow{3}{*}{ Sales } & Downtown Tsuruoka City & $0 \%$ & $35 \%$ & $96 \%$ \\
& Downtown Sakata City & $24,814 \mathrm{mil}$ & $19,159 \mathrm{mil}$ & $13,204 \mathrm{mil}$ \\
& Large stores in Mikawa Town & $24,781 \mathrm{mil}$ & $14,738 \mathrm{mil}$ & $11,979 \mathrm{mil}$ \\
& Mikawa/Both downtown & - & $6,166 \mathrm{mil}$ & $15,340 \mathrm{mil}$ \\
\hline
\end{tabular}

Source: Census of Commerce (METI (Ministry of Economy, Trade and Industry) \& Yamagata Prefecture).

\subsection{Considerations for Case 1}

This case looks very simple, but presents a real picture of local regions of Japan. From a geographical point of view, the traditional downtowns are located in the centre of each urbanized area, which is supposed to be optimum location for customer catchment because they are centres of urban areas where most of the people live. Besides, the train terminals as the gate of the city are located nearby and are close to the public transportation network hubs including bus services.

On the contrary, the newly developed retail district is located far from residential accumulations, which are both urban areas of the two cities. It is no convenient transport access but automobile. However, regarding the accessibility for automobile, $10 \mathrm{~km}$ from urban areas without traffic congestion means less than 15 min's drive. In addition, large number of free parking spaces provided by the new commercial facilities attract automobile users.

It sounds different from common sense, but the above facts indicate that places outside urban area are more convenient and more accessible for automobile users rather than places inside urban area as long as there are arterial roads. Therefore, it can be said that in case of automobile users are majority of residents in the region, the positional reverse between inside and outside of the urban area will occur inevitably. Thus, in a matured motorized society, the optimum location of regional retail accumulation shifts from a central district of urban area to outside of urban area, especially between urban areas. This two cities' case eloquently demonstrates the truth of the geographical upset caused by motorization.

\section{Case 2: Two New Retail Accumulations That Sandwich a Traditional Town Centre}

\subsection{Outline of the Case City}

The second case is two new large retail accumulations located in northern and southern sides of urban fringe area. Each accumulation is about $5 \mathrm{~km}$ away from the central station of the city, which is the centre of the traditional downtown of the city. Both new retail accumulations consist of some large-scale commercial facilities including a suburban large-scale shopping mall with more than $10,000 \mathrm{~m}^{2}$ of retail floor (Table 2). The two new retail accumulations sandwich the urban area of Yamagata City, the downtown where there is traditional retail accumulation.

Yamagata City is a capital city of Yamagata prefecture, the same prefecture as in Case 1 but in a different region. The place is called Yamagata Basin with approximately 40,000 ha of plane fields surrounded by mountains. Yamagata City is bigger than the two cities of the Case 1 in terms of population which is approximately 250,000 and size of urbanized area which is approximately 3,000 ha (as DID (densely inhabitant district) defined by the National Statistic Survey of Japan), whereas Tsuruoka 
Table 2 Major large stores in north and south retail accumulation district $\left(\mathrm{m}^{2}\right)$.

\begin{tabular}{|c|c|c|c|c|c|}
\hline \multicolumn{3}{|c|}{ Northern district (Mamigasaki) } & \multicolumn{3}{|c|}{ Southern district (Wakamiya) } \\
\hline Large stores & Retail floor & Year & Large stores & Retail floor & Year \\
\hline Mega shopping mall & 21,822 & 1997 & Mega shopping mall & 28,782 & 2000 \\
\hline Furniture store & 6,674 & 1997 & Furniture store & 5,635 & 2000 \\
\hline DIY store & 5,363 & 1996 & Electronics store & 4,959 & 2000 \\
\hline Sports goods & 3,142 & 2005 & Sports goods & 2,452 & 2002 \\
\hline Others & 4,280 & - & Drug store & 3,060 & 2000 \\
\hline District total & 41,281 & & District total & 44,888 & \\
\hline
\end{tabular}

Source: Annual Report on Registration of Large Scale Retail Stores (METI).

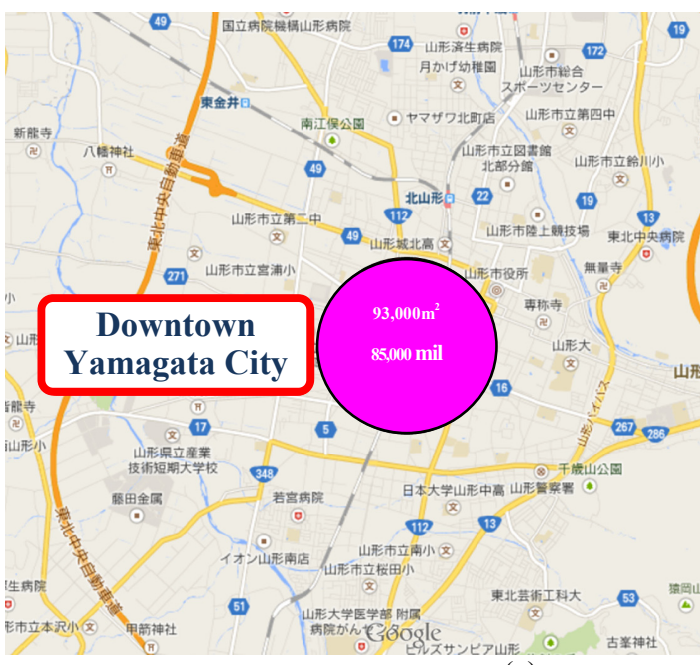

(a)

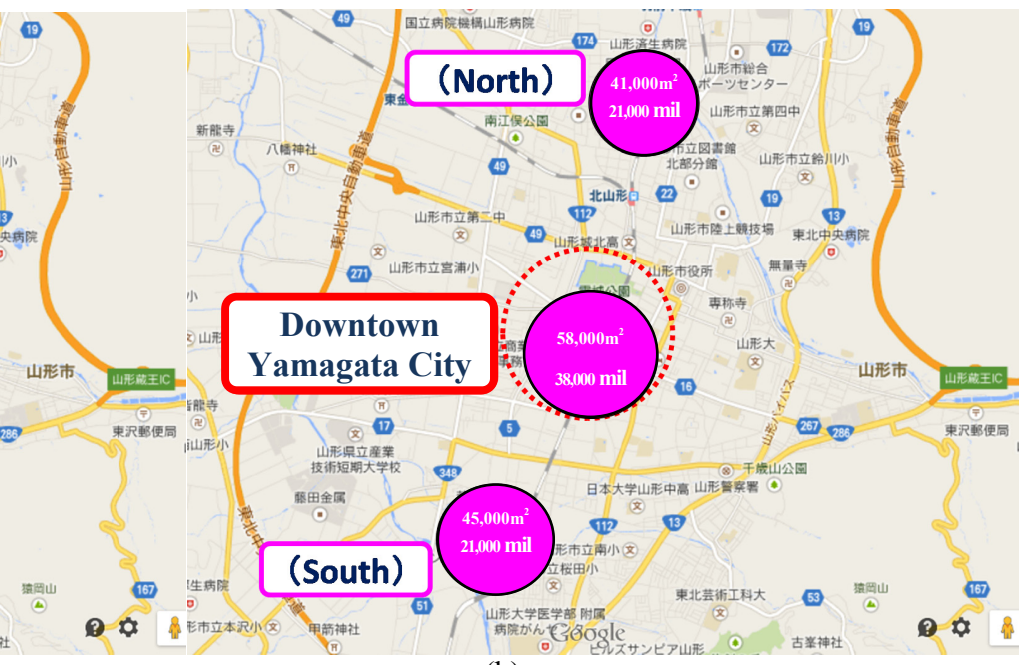

(b)

Fig. 2 Change of retail accumulation in Yamagata City (1994, 2007): (a) retail accumulation district in Yamagata City (1994); (b) retail accumulation districts in Yamagata City (2007).

Table 3 Change of retail accumulation in Yamagata City $(1994,2007)$.

\begin{tabular}{|c|c|c|c|c|c|}
\hline \multirow{2}{*}{\multicolumn{2}{|c|}{ Retail accumulation }} & \multicolumn{2}{|c|}{1994} & \multicolumn{2}{|c|}{2007} \\
\hline & & Quantity & Share & Quantity & Share \\
\hline \multirow{4}{*}{ Floor } & Downtown & $92,957 \mathrm{~m}^{2}$ & $30.0 \%$ & $57,894 \mathrm{~m}^{2}$ & $14.4 \%$ \\
\hline & North district & 0 & $0 \%$ & $41,281 \mathrm{~m}^{2}$ & $10.3 \%$ \\
\hline & South district & 0 & $0 \%$ & $44,898 \mathrm{~m}^{2}$ & $11.2 \%$ \\
\hline & City total & $309,810 \mathrm{~m}^{2}$ & $100.0 \%$ & $402,577 \mathrm{~m}^{2}$ & $100.0 \%$ \\
\hline \multirow{4}{*}{ Sales } & Downtown & $85,267 \mathrm{mil}$ & $24.6 \%$ & $38,112 \mathrm{mil}$ & $11.9 \%$ \\
\hline & North district & 0 & $0 \%$ & $20,528 \mathrm{mil}$ & $6.4 \%$ \\
\hline & South district & 0 & $0 \%$ & $20,988 \mathrm{mil}$ & $6.5 \%$ \\
\hline & City total & 348,004 mil & $100.0 \%$ & $321,780 \mathrm{mil}$ & $100.0 \%$ \\
\hline
\end{tabular}

Source: Census of Commerce (METI \& Yamagata Prefecture).

and Sakata have 1,340 ha and 1,620 ha of land, respectively.

\subsection{What Happened?}

The two new retail accumulations were developed rapidly in a short time. Table 2 shows the floor of major large retail stores and opening year in northern and southern accumulation districts. Most of the retail stores were established in 1997 in the northern district and in 2000 in the southern district. Now Yamagata City has three districts that have more than $10,000 \mathrm{~m}^{2}$ of retail floor: the downtown, the northern district and the southern district.

Fig. 2 and Table 3 show a comparison between 
before and after the new retail accumulations were established. Fig. 2a describes the former size of retail accumulation in the downtown in 1994 before the new retail accumulations were established. It had 92,957 $\mathrm{m}^{2}$ of total retail floor with 85,267 million yen of annual retail sales. Those shares were $30.0 \%$ and $24.6 \%$ of the whole city, respectively.

Fig. $2 \mathrm{~b}$ shows the changed situation in 2007 after the two new retail accumulations were established in northern and southern urban fringe areas. Total amount of annual retail sales of the two newly developed districts exceeds a bit that of the traditional downtown. Total amount of retail floor in the downtown severely decreased. It fell to lower amount than total of the two new districts.

\subsection{Considerations for Case 2}

According to these data, the new retail developments in the urban fringe areas definitely affected the old central downtown. More precisely, each northern and southern new retail accumulation, located in fringe of the urban area, does not exceed amount of the downtown. But the total of the two new accumulations remarkably exceeds the downtown.

This case tells us that only two huge-scale suburban retail developments with large amount of parking lots are able to deprive approximately half amount of the whole sales of the traditional downtown area instead of the traditional downtown. They are located at the opposite sides of urban fringe, which is advantageous location because not only half of the residents in the urban area but also residents living outside the urban area can easily access the places by automobile.

Therefore, it also sounds different from common sense, but the above fact indicates that the urban fringe is possible to be a more accessible location for automobile users rather than the centre of the urban area as long as it is located along arterial roads which are easy to drive on such as a ring road.

\section{Comparing the Two Cases}

Comparing the two cases above, they look like opposite. That is, the first case is a new retail accumulation established between two old cities, whereas the second case is two new retail accumulations sandwiching the urban area. Therefore, we can easily notice that the two cases are in opposite geographical settings. In other words, the first case means that the new one in the middle destroys the old two in both sides, whereas the second case means that the new two in both fringes destroy the old one in between. Then, what is the essential difference between the two cases?

Figs. $3 a$ and $3 b$ abstract the difference between the two cases. Seeing the figures in comparison with the two cases, we can notice two major differences: one is positional relation between the locations of new retail accumulations and the DIDs, and the other is the distance between the old and the new.

Considering the distance regarding the necessary access time for the automobile users to the new retail accumulations, it can be found that each average access time of the two cases are almost exactly the same. In the first two-city case, the distance from the centres of two urban areas to the new retail districts is both approximately $10 \mathrm{~km}$, and the both access routes are high speed arterial roads in rice fields between the cities. So, it can be estimated that the average access time would be around $15 \mathrm{~min}$. In the second case, both two new retail accumulations are located at approximately $5 \mathrm{~km}$ distance from the centre, and alongside of the access routes are densely urbanized building sites. So, it can be estimated that the average access time would be also around $15 \mathrm{~min}$.

In conclusion, it can be said that the two cases are seemingly in opposite settings from a geographical point of view, but from retail developers' point of view, we can find that the two cases are very similar. The sites of new retail accumulations are both located at places of about 15 min's drive on average from residential accumulation areas, nearby arterial roads, 


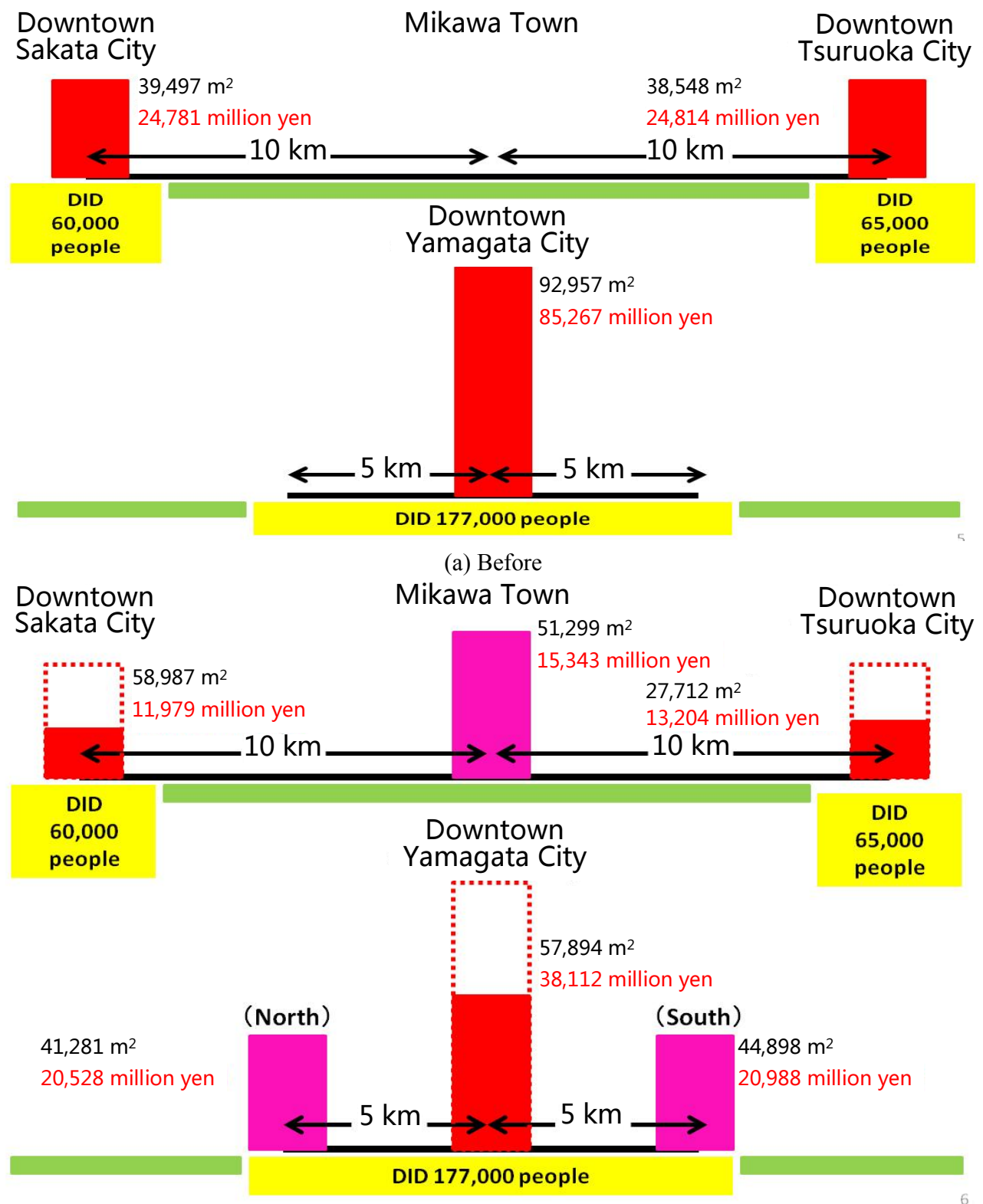

(b) After

Fig. 3 Situation of retail accumulation districts.

large inexpensive sites available to prepare large amount of parking spaces. Therefore, it can be recognized that these are the optimum locations for retail developments in matured motorization era.

\section{Case 3: Large Retail Developments in Small Municipalities}

\subsection{What Happened?}

The third case is a story of Toyota City and the surrounding municipalities. Toyota City is well known as a home town of Toyota Automobile Company, with a population of 409,000 . It is located in the eastern end of the large flat field of Nobi plane. So eastern neighbour municipalities have a mixed landscape that consists of farmlands, residential settlements and factory sites, whereas western sides are non-urbanized mountain areas.

According to the municipal policy, land use regulation in Toyota City is relatively strict compared to the surrounding municipalities. Traditionally, 
large-scale retail store developments have been restricted in suburban areas of Toyota City. In addition to that, when a new land development project was carried out to establish new research facilities in suburban area within Toyota City, the municipal government of Toyota City introduced a new land use regulation to prohibit large retail development with more than $3,000 \mathrm{~m}^{2}$ retail floor by a local ordinance and applied it to the new developments in the suburbs. It was the year of 1997.

Fig. 4 describes the scene that large scale shopping malls with more than $10,000 \mathrm{~m}^{2}$ of retail floor were established one by one in neighbour municipalities of Toyota City. It happened only within three years after
1997 when the municipal government of Toyota City introduced the ordinance to prohibit large retail development in the suburbs.

Actually, the ordinance of Toyota City is only valid within the territory of Toyota City. So it was impossible to prohibit these large-scale shopping mall developments that are located outside Toyota City unless the neighbour municipalities would introduce the same sort of ordinance as Toyota City. Consequently, many huge-scale shopping malls were established one after another in neighbour municipalities. As a result, retail sales share of Toyota City in the region decreased (Table 4).

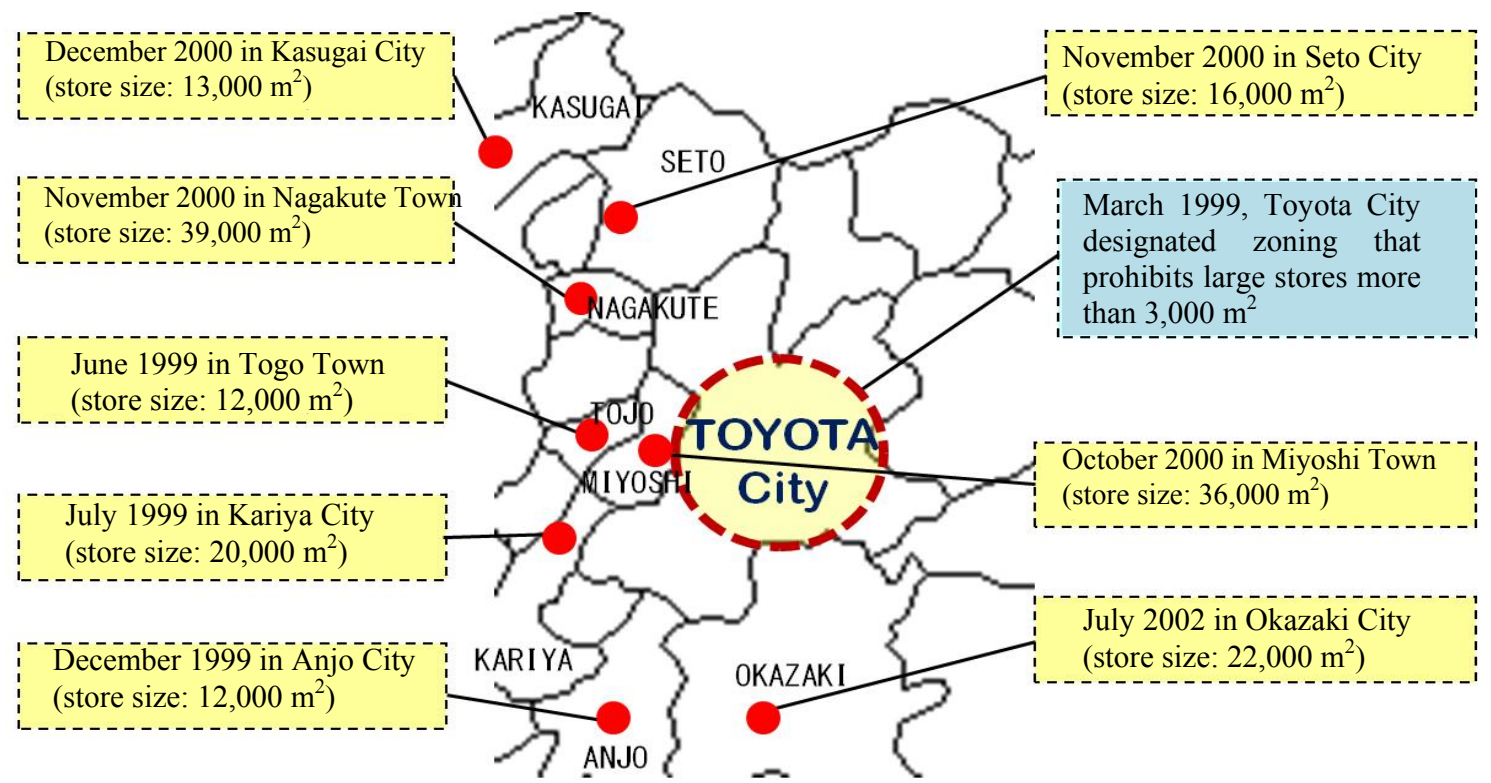

Fig. 4 Large store establishment in Toyota and neighbor municipalities.

Source: Annual Report on Registration of Large Scale Retail Stores (METI).

Table 4 Change of retail sales share in Toyota and neighbour municipalities.

\begin{tabular}{|c|c|c|c|c|c|}
\hline \multirow{2}{*}{ Municipality } & \multicolumn{3}{|c|}{ Retail floor $\left(\mathrm{m}^{2}\right)$} & \multicolumn{2}{|c|}{ Sales share } \\
\hline & 1997 & 2002 & Difference & 1997 & 2002 \\
\hline Toyota & 369,797 & 338,409 & $-31,482$ & $27.9 \%$ & $26.2 \%$ \\
\hline Seto & 105,824 & 126,303 & 20,469 & $7.9 \%$ & $7.3 \%$ \\
\hline Nagakude & 37,074 & 59,458 & 22,384 & $3.5 \%$ & $3.9 \%$ \\
\hline Kariya & 148,080 & 154,752 & 6,672 & $11.8 \%$ & $11.2 \%$ \\
\hline Miyoshi & 32,146 & 60,929 & 28,783 & $2.2 \%$ & $4.0 \%$ \\
\hline Chiryu & 89,141 & 92,821 & 3,680 & $5.2 \%$ & $5.3 \%$ \\
\hline Anjo & 179,929 & 193,587 & 13,658 & $12.5 \%$ & $13.7 \%$ \\
\hline Okazaki & 417,211 & 460,500 & 43,289 & $29.0 \%$ & $28.5 \%$ \\
\hline Total & $1,379,206$ & $1,486,759$ & 107,553 & 1,448 (mil) & 1,370 (mil) \\
\hline
\end{tabular}

Source: Census of Commerce (METI). 


\subsection{Considerations for Case 3}

Why did they happen? Why can such huge malls be developed even in small municipalities? Two reasons are easily thought: one is that the customer catchment areas of these large malls are so wide and broad that they can even reach the suburban residents of Toyota City beyond the boundaries of their municipalities.

The other reason is that all the municipalities except Toyota City welcome large mall establishments within their territories because large malls would contribute to the local economy of the municipalities, especially tax income.

Giving the two reasons above a further consideration, it can be concluded that a municipal government with small territory is not an adequate body in charge of development control on such facilities with wider catchment area than their municipal boundary as large scale commercial facilities.

As we can see, neighbouring municipalities are in competitive relationship with each other in terms of selecting location of facilities with large catchment area. Therefore, it is often seen that a small municipality invites large-scale retail establishment to their territory for their economic interests, or at least, in order to avoid falling in a disadvantageous position in the neighbourhood region by the case that a large store would be located outside their territory. The above twin cities case (Case 1) also corresponds to this kind of pattern because the site of the new large retail development was located in a small town called Mikawa, not in either territory of twin cities.

Thus, as conclusion of this thought, it is not adequate that a municipal government with a limited territory takes responsibility for the specific planning on potential location of large scale commercial development with large catchment area, at least planning without checking and consent of its upper regional jurisdictional government. It must be said that the size of catchment area of the development and the size of territory of a responsible planning authority should be spatially consistent, even in the localism era.

\section{Conclusions}

Major findings from three cases above are as follows: According to progress of motorization, optimum location for retail accumulation changed from the centre of urban area to fringe area and even outside of urban area as long as it is well accessible by arterial roads. This phenomenon corresponds to a local city region where majority of people use their own automobiles for shopping.

By observing the actual cases, the location in the outskirt of urban area, in the middle of two cities as well as the locations sandwiching the urban area were demonstrated as examples of optimum location for retail accumulation rather than central downtown in a motorized local city region. Both locations are approximately $15 \mathrm{~min}$ by automobile from the centre of urban area. These simple patterns occur naturally in the market with progressed large retail facilities. Therefore, they can be said as theoretical optimum patterns of location for large retail accumulation in highly motorized wealthy local cities, though it seems different from former common sense of spatial planning.

Regarding development control on location, Case 3 as well as Case 1 proved that a municipal government with small territory is not an appropriate body for land use planning with large catchment area such as large retail establishment because neighbourhood municipalities are in competitive relationship with each other. Theoretically speaking, the scale of catchment area of the development and the scale of territory of a responsible planning authority should be consistent, even in the localism era.

Lastly, I would like to consider what the fundamental problem of retail sprawl is.

In a highly motorized society, most of the families 
have their own automobiles. Therefore, market is naturally led by automobile users who are the majority of people. Urban habitat space itself tends to change its spatial form to more friendly to automobile than pedestrian such as suburban location with broad road that is far from train station and too large to walk around. Automobile has characteristics to equalizing any places in and out of the city as long as there are arterial roads, but also requires large amount of parking space as a result. Location of every facility including retail stores is driven to spread out.

However, even though the majority consists of people who use automobiles, people who do not use automobiles are not the minority. There are so many automobile-poor people who are not able to use their own cars for some reasons such as economy, age, physical disability or simply unsuitable to drive. Thus, it is supposed that the most crucial problem caused by retail sprawl is alienation of automobile-poor people.

An urban form should not be automobile dependent, not only for greenhouse gas reduction but also more for social inclusiveness. Large scale commercial accumulation is a place for all the residents. Therefore, it should be accessible by all the means of transport, not only automobile. To avoid retail sprawl is one of the most significant issues for spatial planning in matured motorization era.

In view of administrative framework of spatial planning, following two suggestions could be led by considering the background conditions of Japanese case.

First one is concerning the so-called localism policy or decentralization in relation to land use regulation. Japan has two layered local government, that is prefectural government and municipal government such as cities, towns and villages. During 20th century, when Japan still had been in developing stage and public investment was the largest issue, planning administration had been basically led by prefectural governments and more or less with the national government. However, authority for planning regulation had been transferred to municipal government step by step and finally most of the power for land use regulation has belonged to city government since 1998. After that, most of the prefectural governments are seemed lost their interest in implementation of planning regulations except for the issues related to their own authority. Case 3 is an example because no indication of intervention by prefectural government is found even though there is apparent regional influence beyond the municipal boundaries by such huge stores. But they did simply not to exceed their authority. After all, the problem is wrong allocation of authority by the law lacking appropriate consideration on spatial scale.

Second one is concerning start line of land use regulation. According to the statutory system of land use regulation in Japan, any land use is allowed only by procedure of certification, no permission which means without any discretion, as long as it is not incompatible to the zoning code. The zoning code is ordinary very generous especially in outer area of the city [9], which reason is that it is principally thought that regulation should not be imposed without obvious necessity. In the old days, land use regulation did not anticipate the kind of stores that have huge area of shopping floor but low ratio of floor area density established in the outer suburbs. It was only supposed that stores with huge shopping floor were usually high density buildings like department stores in downtown. Therefore, the zoning code did not regulate retail buildings by size of shopping floor. It regulated stores only by floor area ratio until 2006 when the national laws were amended. However, suburban shopping mall has huge floor area but low density, that is an unexpected phenomenon and that is the main reason why huge scale commercial facilities were easily established in outer areas as the above cases.

Traditionally, there are two opposite positions in terms of the principle of regulation system. One position asserts that regulation should be always minimum and should not be imposed without obvious 
necessity, while the other position asserts that regulation should be originally widely applied in order to prevent unexpected harms. There have been long and fundamental discussions between the two opposite positions, but as long as the sprawl phenomenon of large scale commercial facilities is concerned, the above cases suggest that the latter position is required.

\section{References}

[1] Cabinet Office of Japan Public Opinion Survey on Retail Stores, 2005, http://www8.cao.go.jp/survey/h17/ h17-kouri/2-3.html (accessed Feb. 5, 2014).

[2] T. Akashi, A research on land use planning system to control locations of regional retail functions, Working paper, The University of Tokyo, 2005, pp. 139-188.

[3] PPG6, Town Centre and Retail Development,
Department of Environment, The United Kingdom for the Stationery Office, UK, 1996.

[4] PPS6, Planning for Town Centres, Office of Deputy Prime Minister, The United Kingdom for the Stationery Office, UK, 2005.

[5] B.D. Howard, R.L. Davies, The impact of regional out-of-town retail centers-The case of the metro center, Progress in Planning 40 (1993) 89-165.

[6] C. Guy, Development pressure and retail planning: A study of 20-year change in Cardiff, UK, The International Review of Retail, Distribution and Consumer Research 20 (1) (2010) 119-133.

[7] T. Akashi, M. Banba, A study on call-in policy for retail development in England, Journal of the City Planning Institute of Japan 43 (2) (2008) 19-24.

[8] R. Hotelling, Stability in competition, Economic Journal 39 (1929) 41-57.

[9] T. Akashi, Current status of land use regulation system for controlling large scale retail stores, City Planning 241 (2003) 89-98. 